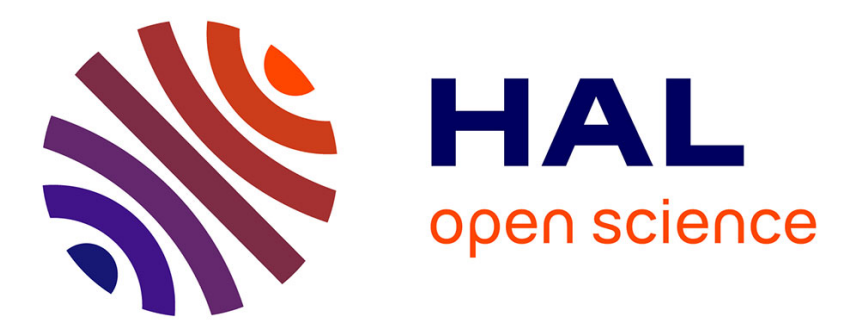

\title{
RAPID applied to the SIM-France model
}

Cédric H. David, Florence Habets, David R. Maidment, Zong-Liang Yang

\section{To cite this version:}

Cédric H. David, Florence Habets, David R. Maidment, Zong-Liang Yang. RAPID applied to the SIM-France model. Hydrological Processes, 2011, 25 (22), pp.3412-3425. 10.1002/hyp.8070 . hal$00641722 \mathrm{v} 2$

\section{HAL Id: hal-00641722 \\ https://hal.science/hal-00641722v2}

Submitted on 18 Nov 2011

HAL is a multi-disciplinary open access archive for the deposit and dissemination of scientific research documents, whether they are published or not. The documents may come from teaching and research institutions in France or abroad, or from public or private research centers.
L'archive ouverte pluridisciplinaire $\mathbf{H A L}$, est destinée au dépôt et à la diffusion de documents scientifiques de niveau recherche, publiés ou non, émanant des établissements d'enseignement et de recherche français ou étrangers, des laboratoires publics ou privés. 
3 Cédric H. David ${ }^{1,2,3}$ (cedric.david@mail.utexas.edu), Florence Habets ${ }^{4}$

$4 \quad$ (florence.habets@mines-paristech.fr), David R. Maidment ${ }^{2}$ (maidment@mail.utexas.edu)

5 and Zong-Liang Yang ${ }^{3}$ (liang@,mail.utexas.edu)

6

7 1. Centre de Géosciences, Mines Paristech, Fontainebleau, France

8 2. Center for Research in Water Resources, University of Texas at Austin, Austin, Texas, 9 USA.

10 3. Department of Geological Sciences, Jackson School of Geosciences, University of

11 Texas at Austin, Austin, Texas, USA.

12 4. UMR-7619 Sisyphe [CNRS, UPMC, Mines-Paristech], Paris, France.

\section{Corresponding author}

15 Cédric H. David

16 Department of Geological Sciences, Jackson School of Geosciences

17 The University of Texas at Austin

181 University Station C1160

19 Austin, TX 78712

20 cedric.david@mail.utexas.edu

$21+15122997191$ (cell)

$22+15124715355$ (office)

23 (No fax number available) 


\section{Abstract}

25 SIM-France is a large connected atmosphere/land surface/river/groundwater modeling

26 system that simulates the water cycle throughout metropolitan France. The work

27 presented in this study investigates the replacement of the river routing scheme in SIM-

28 France by a river network model called RAPID to enhance the capacity to relate

29 simulated flows to river gages and to take advantage of the automated parameter

30 estimation procedure of RAPID. RAPID was run with SIM-France over a ten-year

31 period and results compared with those of the previous river routing scheme. We found

32 that while the formulation of RAPID enhanced the functionality of SIM-France, the flow

33 simulations are comparable in accuracy to those previously obtained by SIM-France.

34 Sub-basin optimization of RAPID parameters was found to increase model efficiency. A

35 single criterion for quantifying the quality of river flow simulations using several river

36 gages globally in a river network is developed that normalizes the square error of

37 modeled flow to allow equal treatment of all gaging stations regardless of the magnitude

38 of flow. The use of this criterion as the cost function for parameter estimation in RAPID

39 allows better results than by increasing the degree of spatial variability in optimization of

40 model parameters. Likewise, increased spatial variability of RAPID parameters through

41 accounting for topography is shown to enhance model performance.

42

43 Keywords stream flow, river network, network matrix, parameters, estimation, dam, quad-

44 tree

45 


\section{Introduction}

47 In the past two decades, several large scale river routing schemes have been used along

48 with land surface models for hydrologic modeling. Among the most notable applications

49 of large scale river routing are TRIP [Total Runoff Integrating Pathways, Ngo-Duc, et al.,

50 2007; Oki and Sud, 1998], RiTHM [River-Transfer Hydrological Model, Ducharne, et

51 al., 2003], the routing model of Lohmann et al. [Lohmann, et al., 1996; 1998a; 1998b;

52 1998c; 2004; Maurer, et al., 2001], that of Wetzel [Abdulla, et al., 1996; Nijssen, et al.,

53 1997; Wetzel, 1994], and that of Olivera et al. [2000]. These approaches have been used

54 along with land surface parameterization schemes to calculate river flow from runoff at

55 the regional, continental and the global scale. MODCOU [Modèle Couplé, Ledoux, et

$56 a l ., 1989]$ is another model with routing capabilities that differs from the previously cited

57 models in that it has two separate networks of grid cells for horizontal routing of water on

58 the land surface: one for overland routing and one for routing within the river system.

59 MODCOU simulates flows throughout Metropolitan France (mainland France and

60 Corsica) as part of the SIM-France modeling framework [Habets, et al., 2008].

61 SIM-France (SAFRAN-ISBA-MODCOU-France) is a large connected atmosphere, land

62 surface, river and groundwater model (see Figure 1) that involves coupling the national-

63 scale atmospheric analysis system SAFRAN [Système d'Analyse Fournissant des

64 Renseignements Atmosphériques à la Neige, Durand, et al., 1993; Quintana-Segui, et al.,

65 2008], with the ISBA land surface model [Interactions Soil- Biosphere-Atmosphere,

66 Boone, et al., 1999; Noilhan and Planton, 1989], and with the MODCOU

67 hydrogeological model [Ledoux, et al., 1989]. ISBA computes the vertical water and

68 energy balance between the land surface and the atmosphere. The improved physics of 
69 the land surface parameterization of ISBA that consist of an exponential profile for soil

70 hydraulic conductivity developed in Decharme et al. [2006] with calibration of soil

71 hydraulic conductivity and subgrid runoff over France by Quintana-Seguí et al. [2009]

72 are used in this study. Surface runoff and deep-soil drainage are computed by ISBA and

73 transferred to MODCOU which computes the horizontal flow routing on the land surface,

74 in rivers and in aquifers. Aquifers in MODCOU are modeled within the two main river

75 basins of France, the Seine and the Rhône, which together represent $30 \%$ of the land area

76 of France.

77 MODCOU handles the calculations of flow and volume of water within the river network

78 of SIM-France. This river network is made up of grid cells divided into a quad-tree

79 pattern and the calculations of MODCOU are made for groups of quad-tree cells; not for

80 each quad-tree cell separately. Using groups of cells for calculations is advantageous for

81 reducing computational costs but it limits the modularity of MODCOU. In particular, the

82 location and number of gaging stations are difficult to modify.

83 The work presented herein investigates the impact of replacing the routing module used

84 in MODCOU by a river network model called RAPID [Routing Application for Parallel

85 ComputatIon of Discharge, David, et al., 2011]. RAPID uses a matrix-based version of

86 the Muskingum method to calculate flow and volume of water for each reach of a river

87 network separately and has an automated parameter estimation procedure. RAPID

88 therefore allows greater flexibility than the routing module in MODCOU with regards to

89 changing the locations of computations in an existing domain or to running SIM on a new

90 domain. RAPID was previously applied to a GIS vector river network [David, et al.,

91 2011], and the present study shows how it can also be applied to a quad-tree gridded river 
92 network. In addition, RAPID is advantageous because of its ability to run in a parallel 93 computing environment and its fine time step allowing potential comparison with river

94 flow observations at high temporal resolution. Finally, replacing the routing module of 95 MODCOU by RAPID has already allowed computing river flow height and helping

96 quantify river/aquifer interactions at the regional scale [Saleh, et al., 2010; 2011].

97 In this paper, the original river routing of MODCOU as well as that of RAPID are briefly

98 presented followed by a ten-year application (1995-2005) of SIM-France comparing the

99 two river routing applications for different sets of parameters used in RAPID.

100 


\section{2.1. River modeling in SIM-France}

103 The computational domain of SIM-France includes all of Metropolitan France, including

104 Corsica. Parts of Spain, Switzerland, Germany and Belgium are also included where

105 their drainage area flows through France, as shown in Figure 2. The total surface area of

106 the computational domain is $610,000 \mathrm{~km}^{2}$.

107 Surface routing and river routing in SIM-France are done by MODCOU [Ledoux, et al.,

108 1989]. The surface and river networks of SIM-France and their connectivity were created

109 using a routine called HydroDem [Leblois and Sauquet, 2000] and consist of 193,861

110 surface cells and 24,264 river cells, each river cell being a particular surface cell. The

111 surface area covered by the river cells is $65,000 \mathrm{~km}^{2}$. The surface network uses a quad-

112 tree structure with cell sizes of $1 \mathrm{~km}, 2 \mathrm{~km}, 4 \mathrm{~km}$ and $8 \mathrm{~km}$. The river network has cell

113 sizes of $1 \mathrm{~km}$ and $2 \mathrm{~km}$. The smaller quad-tree cells are used at the conference of

114 branches of the river network for better representation of the network connectivity and at

115 basin boundaries for more accurate basin surface area.

116 The connectivity between river cells is given by a table that provides for each

117 downstream river cell up to three upstream river cells. There are no loops or divergences

118 in the river network of SIM-France. The connectivity between catchments and rivers is

119 given by a table that provides for each surface cell a unique downstream cell where its

120 runoff enters the river.

121 For both surface and river routing, the calculations of flow and volume of water within

122 MODCOU are carried out using groups of cells as computing elements, therefore

123 minimizing the amount of calculations compared to computing for all cells separately. 
124 These groups of cells - or isochrone zones - are based on the notion of isochronism 125 developed by Leblanc and Villeneuve [1978]. An isochrone is a line representing a

126 constant time of travel to a reference point downstream. An isochrone zone is the area

127 between two successive isochrones. This zone is represented by a set of cells which are a

128 single computational unit in MODCOU. Both the land surface isochrones and river

129 isochrones of MODCOU have three-hour time intervals, which means that the time of

130 travel between the upstream-most and the downstream-most cell in a given isochrone

131 zone is approximately three hours. All the isochrones of a given network are determined

132 using the travel time between connected cells which is estimated based on topography

133 and on the geometry of the quad-tree mesh. For surface cells and river cells, the travel

134 time $\tau_{i, j}$ between two consecutive cells $i$ and $j$ is calculated using the distance

$135 d_{i, j}$ between the two cells and the slope $s_{i, j}$, as shown in Equation (1):

$$
\tau_{i, j}=\alpha \cdot \frac{d_{i, j}}{\sqrt{s_{i, j}}}
$$

139 where $\alpha$ is the inverse of a velocity. In the current version of SIM-France, a unique

140 value of $\alpha$ is calibrated for each major basin.

141 Figure 3 shows an example of the isochrone zones and connectivity between surface cells 142 and river cells in MODCOU for the Ardèche River Basin. Figure 3a) shows the Ardèche 143 River, its basin and three river gages. Figure $3 b$ ) shows the river isochrone zones of the 144 Ardèche River. Figure 3c) shows the surface isochrone zones corresponding to the 145 upstream-most river isochrone zone. Each surface cell belongs to a surface isochrone 
146 zone, but only the isochrone zones corresponding to one river isochrone zone are shown

147 of Figure 3c) for clarity. The units used for isochrone zones are the number or

148 MODCOU 3-hour time steps to the outlet (here the Mediterranean). The quad-tree

149 structure of increasing resolution can be seen at the boundary of the basin in Figure 3c).

150 In MODCOU, the volume of water $V^{\text {out }}$ that discharges across each isochrone line in a

151 computation time step is calculated differently for the surface network and for the river

152 network. For routing on the land surface, all the volume of water $V$ available in the

153 isochrone zone is transferred to the downstream zone, as shown in Equation (2):

$$
V^{\text {out }}=V
$$

157 For routing in the river network, $V^{\text {out }}$ is proportional to the volume of water $V$ available

158 within the isochrone zone as shown in Equation (3):

$$
V^{\text {out }}=\beta \cdot V
$$

162 where $\beta \in[0,1]$ is manually calibrated and usually set constant for large basins. Equation

163 (3) can be viewed as the linear reservoir equation associated with a first-order explicit

164 development of the continuity equation. The variation of volume related to lateral inflow 165 and groundwater inflow of water are added to the volume $V$ before calculating $V^{\text {out }}$. In 166 SIM-France, $\beta$ has four possible values: $0.5,0.7,0.8$ and 0.9 as shown in Figure 4. 
167 Equation (3) is applied to isochrone zones. Hence, the volume of water within each

168 isochrone zone needs be partitioned among its several river cells before computation of

169 the river-aquifer exchanges. This interaction depends on the aquifer head, on the river

170 head - assumed constant - and on the volume of water in the river cell when the river

171 infiltrates water into the aquifer. The partitioning of water volume among all cells of an

172 isochrone zone is done using a weighted average of the total amount of water reflecting

173 the spatial distribution of lateral inflow in each isochrone zone.

174 This formulation has several inconsistencies, especially when the junction between two

175 streams lies in the interior of an isochrone zone. This can have a consequence in river-

176 aquifer interactions, but also in the computation of river flow. Furthermore, using only

177 one set of isochrones in each basin can lead to two gages being located in one isochrone

178 zone (for example a zone containing a confluence with gaging stations on both sides), in

179 which case the flow computed by MODCOU has to match the flow at two different

180 gaging stations. In order to avoid such inconsistencies, MODCOU uses a unique set of

181 isochrone zones for each gage, such that each gage is the downstream-most river cell in

182 its isochrone zone. Therefore, several flow calculations can be performed for a given

183 cell, if the given cell belongs to several isochrone zones, which is inefficient and requires

184 time consuming processing work in case of change of number or locations or river gages.

185 The work done herein aims at simplifying the river modeling done within SIM-France

186 and to ensure evolution of the code as for instance the computation of river flow height

187 [Saleh, et al., 2010; 2011] and velocity.

\section{2.2. RAPID}


189 RAPID [David, et al., 2011] is a river network model that uses a matrix-based version of

190 the Muskingum routing scheme to calculate discharge simultaneously through a river

191 network. RAPID was first applied to the Guadalupe and San Antonio River Basins in

192 Texas using a vector-based river network extracted from a geographic information

193 system dataset called NHDPlus [USEPA and USGS, 2007]. The governing equation used

194 in RAPID is the following:

$$
\left(\mathbf{I}-\mathbf{C}_{1} \cdot \mathbf{N}\right) \cdot \mathbf{Q}(t+\Delta t)=\mathbf{C}_{1} \cdot \mathbf{Q}^{\mathrm{e}}(t)+\mathbf{C}_{2} \cdot\left(\mathbf{N} \cdot \mathbf{Q}(t)+\mathbf{Q}^{\mathrm{e}}(t)\right)+\mathbf{C}_{3} \cdot \mathbf{Q}(t)
$$

198 where $t$ is time and $\Delta t$ is the river routing time step. The bolded notation is used for

199 vectors and matrices. All matrices are square. $\mathbf{I}$ is the identity matrix. $\mathbf{N}$ is the river

200 network connectivity matrix which has a value of one in element $N_{i, j}$ if reach $j$ flows

201 into reach $i$ and zero elsewhere. $\mathbf{C}_{\mathbf{1}}, \mathbf{C}_{\mathbf{2}}$ and $\mathbf{C}_{\mathbf{3}}$ are parameter matrices which depend on

202 Muskingum $k, x$ and time step $\Delta t . \mathbf{Q}(t)$ is a vector of outflows from river reaches,

203 and $\mathbf{Q}^{\mathrm{e}}(t)$ is a vector of lateral inflows to these reaches from land surface runoff or

204 groundwater inflow. The number of river quad-tree cells - here 24,264 - is used for

205 dimension of all vectors and matrices, each element of the vectors corresponding to one

206 river cell.

207 Provided with a vector of lateral inflows $\mathbf{Q}^{\mathbf{e}}(t)$, RAPID calculates the flow and volume

208 of water in all reaches of a river network, therefore allowing coupling of a river network

209 to most land surface models and groundwater models. A different value for the

210 parameters $k$ and $x$ of the Muskingum method can be assigned for each river quad-tree 
211 cell, and RAPID uses two vectors $\mathbf{k}$ and $\mathbf{x}$ as input which are used to compute the values

212 of the matrices $\mathbf{C}_{\mathbf{1}}, \mathbf{C}_{\mathbf{2}}$ and $\mathbf{C}_{\mathbf{3}}$. However, before routing with RAPID, horizontal surface

213 and subsurface routing is needed to transport runoff from a land surface cell to its

214 corresponding river cell. In the present study, this surface and subsurface routing is done

215 by MODCOU and RAPID replaces only the river modeling of MODCOU.

216 The connectivity information that already exists between the river cells in the SIM-

217 France river network is used to create the network connectivity matrix $\mathbf{N}$ needed by

218 RAPID and described in David et al. [2011].

219 RAPID uses an automated parameter estimation procedure which, given lateral inflow

$220 \mathbf{Q}^{\mathbf{e}}$ everywhere in the river network, and gage measurements at some locations,

221 determines a best set of parameters based on a square error cost function. As in David et

222 al. [2011], the search for optimal vectors of parameters $\mathbf{k}$ and $\mathbf{x}$ is made by determining

223 two multiplying factors $\lambda_{k}$ and $\lambda_{x}$ such that:

$$
\forall j \in[1,24264] \quad k_{j}^{\rho}=\lambda_{k} \cdot \frac{L_{j}}{c^{0}} \quad, \quad x_{j}^{\rho}=\lambda_{x} \cdot 0.1
$$

227 where $j$ is the index of a quad-tree river cell, $k_{j}^{\rho}$ and $x_{j}^{\rho}$ are its Muskingum parameters,

$228 L_{j}$ is the flow distance within a river cell and $c^{0}=1 \mathrm{~km} \cdot \mathrm{h}^{-1}=0.28 \mathrm{~m} \cdot \mathrm{s}^{-1}$ is a reference

229 celerity for the flow wave. The parameters $k_{j}^{\rho}$ and $x_{j}^{\rho}$ are the same developed in David et

230 al. [2011] and are referred to as $\rho$ parameters in the following. In this study, the size of

231 the side of each quad-tree river cell was used as an approximation of its flow distance. 
232 The value of $\lambda_{x}$ is bounded by the interval $[0,5]$ since the Muskingum method is stable

233 only for $x \in[0.0,0.5]$, as shown in Cunge [1969]. The two scalars $\lambda_{k}$ and $\lambda_{x}$ are

234 determined such that the corresponding vectors $\mathbf{k}$ and $\mathbf{x}$ minimize the value of an

235 optimization criteria, or cost function. At the end of the optimization procedure, one

236 couple $\left(\lambda_{k}, \lambda_{x}\right)$ is determined for a given part of the network. The values of $\lambda_{k}$ and $\lambda_{x}$ can

237 be determined for the entire study domain, or for sub-basins. If a sub-basin is located

238 downstream of another sub-basin, observations at a gaging station are used to provide the

239 upstream flow. Therefore, the delineation of sub-basins has to be consistent with the

240 location of available gage measurements.

241 The optimization procedure uses a line-search algorithm called the Nelder-Mead method

242 [Nelder and Mead, 1965] to determine the two scalars $\lambda_{k}$ and $\lambda_{x}$.

243 The use of RAPID within SIM-France allows for flow and volume calculation at each

244 river cell and RAPID allows for the ready inclusion of additional river gages to be used

245 for calibration.

246 


\section{3. Application of RAPID in France}

\section{3.1. Optimization of RAPID parameters}

249 This section focuses on the optimization of RAPID parameters with various options used

250 for $k_{j}$ and $x_{j}$, for the optimization cost function and for the spatial variability of the

251 optimization. Two formulations are applied for computing $k_{j}$ and $x_{j}$ including one

252 formulation taking topography into account, two cost functions are tested, and three

253 different domain decompositions are used for optimization of parameters. In order to

254 simplify the optimization procedure and to ensure its repeatability, the parameter

255 estimation of RAPID was run uncoupled from SIM-France. Lateral and groundwater

256 inflow to the river network were obtained from a simulation using the standard version of

257 SIM-France (without RAPID) augmented with improved physics of the land surface

258 parameterization of ISBA developed in Decharme et al. [2006] and calibrated over

259 France by Quintana-Seguí et al. [2009]. Daily gage measurements from the French

260 HYDRO database [SCHAPI, 2008] were used for the parameter estimation as well as for

261 comparison with daily-averaged flow calculations .

262 The period of interest of the present study is August $1^{\text {st }} 1995$ to July $31^{\text {st }} 2005$. However,

263 the parameter estimation was performed using five months of the first winter (November

$2641^{\text {st }} 1995$ to March $\left.31^{\text {st }} 1996\right)$. As part of the first year (1995-1996) was used for

265 calibration, separate statistical results are presented for 1995-1996 and 1995-2005.

266 RAPID is run using a 30-minute time step and forced with 3-hourly lateral inflow

267 volumes; daily averages of computed discharge are compared with daily observations at

268 gage locations. There are 907 stations within the river network of SIM-France but only 
269493 of these have daily measurements every day during the first year (August $1^{\text {st }} 1995$ to

270 July $31^{\text {st }}$ 1996). Amongst the 493 available stations, the best 291 were utilized for

271 optimization of RAPID parameters. The criterion used for the selection of the 291 best

272 stations is a Nash efficiency [Nash and Sutcliffe, 1970] better than 0.5 in the existing

273 SIM-France model (without RAPID) over 1995-1996. This selection excludes the gages

274 that are affected either by dams or by water diversions, and thus avoids unrealistic model

275 parameters due to anthropogenic modifications of river flow. Therefore, the proposed

276 routing scheme is optimized at locations were the previous routing scheme already

277 performed well.

278 The optimization is first performed on all rivers of the domain, therefore obtaining unique

279 values of $\lambda_{k}$ and $\lambda_{x}$ for all 24,264 river quad-tree cells. However, such an optimization

280 may not capture the variability between river basins and within sub-basins, due to the

281 various slopes or soil types. Therefore, the optimization procedure was also run

282 independently within the seven main river basins of France shown in Figure 5a) and

283 within the twenty sub-basins shown in Figure 5b).

284 In order to limit the effect of the initial state of the system at the beginning of the

285 optimization procedure, the initial flows on 01 November 1995 were estimated using a

286 simple run of RAPID. This estimation was obtained through running the routing model

287 from 01 August to 31 October 1995 with uniform values of $\lambda_{k}$ and $\lambda_{x}$ over the study

288 domain and initial flows $0 \mathrm{~m}^{3} / \mathrm{s}$ for all river cells on 01 August 1995.

289 The results of a parameter estimation procedure depend slightly on the initial guess for

290 the parameters. Therefore, three different sets of initial guesses for $\lambda_{k}$ and $\lambda_{x}$ were used: 
$291 \quad\left(\lambda_{k}, \lambda_{x}\right)=(2,3),\left(\lambda_{k}, \lambda_{x}\right)=(4,1)$ or $\left(\lambda_{k}, \lambda_{x}\right)=(1,1)$. The numerical values of these three

292 sets have no particular meaning and serve to start the optimization with a different initial

293 value for $\mathbf{k}$ and $\mathbf{x}$. Each set of initial guesses leads to slightly different results for the

294 optimal $\lambda_{k}$ and $\lambda_{x}$. Out of the three sets of optimal $\lambda_{k}$ and $\lambda_{x}$ that are determined for

295 each sub-basin, only the best is kept. This selection is based on the set of parameters that

296 leads to the smallest value of the optimization cost function.

297 Once the optimization procedure was completed, RAPID was run with SIM-France over

298 a 10-year period, from August 1995 to July 2005. This section focuses on the first year

299 while the next section studies the ten-year run. In order to compare the overall

300 performance of both routing models on the river network, the Nash efficiency and the

301 root mean square error (RMSE) were calculated for each of the 493 gaging stations over

302 1995-1996. These criteria are sorted and comparisons between the computations of

303 MODCOU and those of RAPID are shown in Figure 6. The two graphs in Figure 6 do

304 not allow comparing both models at each gaging station since the criteria are sorted, but

305 they depict the overall relative performance of both models. Table 1 shows the average

306 Nash efficiencies and RMSEs obtained by the original version of SIM-France and with

307 RAPID using various optimization procedures. During 1995-1996, 382 stations have a

308 positive efficiency using the standard version of SIM-France. The averages presented in

309 Table 1 show the best 382 values for both efficiency and RMSE, but similar patterns are

310 found for all 493 values or the best 291 values.

311 In its original formulation, the criterion used in the optimization of RAPID is based on a

312 square error cost function $\phi_{1}$. This function is the sum of the square errors between daily 
313 measurements $Q_{i}^{g}(t)$ and daily-averaged $\bar{Q}_{i}(t)$ flow computations for several river

314 gaging stations $i$ and for everyday of a given period of time $\left[t_{o}, t_{f}\right]$, as shown in

315 Equation (6).

316

$$
\phi_{1}(\mathbf{k}, \mathbf{x})=\sum_{t=t_{o}}^{t=t_{f}} \sum_{i=1}^{i=291}\left[\frac{\overline{Q_{i}}(t)-Q_{i}^{g}(t)}{f}\right]^{2}
$$

319 where the summation is made daily and at river cells with active gaging stations only. $t_{o}$

320 and $t_{f}$ are respectively the first day and last day used for the calculation of $\phi_{1}$.

$321 i \in[1,291]$ is the index for gaging stations. The model parameter vectors $\mathbf{k}$ and $\mathbf{x}$ are

322 kept constant within the temporal interval $\left[t_{o}, t_{f}\right]$, and the cost function is calculated

323 several times with different sets of parameters during the optimization procedure. $f$ is a

324 scalar that allows $\phi_{1}$ to be of the order of magnitude of $10^{1}$ which is helpful for automated

325 optimization procedures. One can notice that, in $\phi_{1}$, a given fractional error $(5 \%$ error

326 between modeled and measured flow for example) for two stations with different orders

327 of magnitude for river flow influences the cost function differently. A small fractional

328 error on a gaging station with a large flow penalizes the cost function more than the same

329 fractional error on a gaging station with small flow. The Nash efficiency $E$ is highly

330 influenced by the difference between the model computation and the mean average flow,

331 as shown in Equation (7):

332 


$$
E=1-\frac{\sum_{t=t_{o}}^{t=t_{f}}\left[Q_{i}^{g}(t)-\overline{Q_{i}}(t)\right]^{2}}{\sum_{t=t_{o}}^{t=t_{f}}\left[Q_{i}^{g}(t)-\left\langle Q_{i}^{g}\right\rangle\right]^{2}}
$$

335 where $\left\langle Q_{i}^{g}\right\rangle$ is the average daily flow observed at the gaging station $i$ over a long

336 interval. Therefore, the use of $\phi_{1}$ penalizes the Nash efficiency. In order to avoid that the

337 order of magnitude of flow at each gaging station influences their weight in the cost

338 function, a new cost function $\phi_{2}$ is created, as shown in Equation (8):

$$
\phi_{2}(\mathbf{k}, \mathbf{x})=\sum_{t=t_{o}}^{t=t_{f}} \sum_{i=1}^{i=291}\left[\frac{\overline{Q_{i}}(t)-Q_{i}^{g}(t)}{\left\langle Q_{i}^{g}\right\rangle}\right]^{2}
$$

342 The new cost function $\phi_{2}$ results in the changes shown in Table 1 and Figure 6 where the

343 Nash efficiencies and RMSEs obtained with RAPID using $\phi_{2}$ are better than with $\phi_{1}$.

344 Overall, the Nash efficiencies and the RMSEs in RAPID are comparable while not as

345 good as those obtained with the routing scheme of the original SIM-France. Therefore,

346 the choice of the cost function is crucial to determining a set of optimal parameters. 
347 In order to estimate the effect of more spatial variability in the optimization of RAPID

348 parameters, the parameter estimation was done on different basins and sub-basins. Figure

3497 shows the sorted Nash efficiencies and RMSEs obtained with three degrees of spatial

350 variability of optimization using $\phi_{2}$ as the cost function. These spatial variabilities

351 include "France" which has uniform parameters over the whole domain, "basins" for the

3527 river basins of Figure 5a) (Adour, Garonne, Loire, Seine, Meuse, Rhône and Hérault)

353 and "sub-basins" where the major river basins have been divided into 20 sub-basins as

354 shown in Figure 5b). The increase in spatial variability of optimization increases the

355 efficiency while the RMSE remains almost constant, but the increase in efficiency is

356 limited compared to that triggered by a change in the cost function. The values of

357 parameters $\lambda_{k}$ and $\lambda_{x}$ obtained with the parameter estimation procedure using the second

358 cost function are shown in Table 2.

359 The number of gaging stations in a basin can be divided by the number or river cells in

360 the basin to calculate an observability ratio $O$, as done in Table 2. This ratio ranges from

$361 O=22$ on the Ardèche River to $O=1307$ downstream of the Seine River, showing a wide

362 spread in density of observations. The Seine River, of great interest to the French

363 community, has a higher resolution and therefore more river cells in SIM-France than any

364 other basin - all the river cells are of size $1 \mathrm{~km}$ - which explains the lower observability

365 ratio. Unrealistically low results are obtained for $\lambda_{k}$ in the downstream part of the Seine

366 River and for the Ardèche River Basin. The former is explained by the limited amount of

367 stations used for optimization in the downstream part of the Seine River Basin (only one

368 station). The latter is due to the basin being small with regards to the number of gages 
369 (leading to a low observability ratio) and therefore over-constraining the optimization

370 procedure. The observability ratio is therefore a key metric for the quality of the

371 optimization. These unrealistic values for $\lambda_{k}$ may partly explain why the effect of

372 optimization from 7 basins to 20 sub-basins is very limited. As expected, the

373 optimization procedure converges to the largest values of the parameter $\lambda_{k}$ for the Seine

374 and Loire rivers which are the slowest rivers. For each of the 7 major basins, the value of

$375 \lambda_{k}$ is bounded by the value of $\lambda_{k}$ for each of their corresponding sub-basins. Also, one

376 can notice that upstream parts of a basin are usually faster (lower $\lambda_{k}$ ) than downstream

377 parts as can be seen for the upstream part of the Loire Basin, and for the Allier Basin

378 which are located in high topography areas. This shows that - as expected - topography

379 plays an important role in the travel time of flow waves. This motivates a final

380 experiment where RAPID model parameters are estimated based on topography as shown

381 in Equation (9).

$$
\forall j \in[1,24264] \quad k_{j}^{\sigma}=\lambda_{k} \cdot \alpha \cdot \frac{d_{i, j}}{\sqrt{s_{i, j}}} \quad, \quad x_{j}^{\sigma}=\lambda_{x} \cdot 0.1
$$

385 This formulation of $k_{j}^{\sigma}$ is adapted from Equation (1) which is used to determine the

386 location of isochrone zones. In the following, the parameters $k_{j}^{\sigma}$ and $x_{j}^{\sigma}$ of Equation (9)

387 are referred to as $\sigma$ parameters. Table 1 shows the average efficiencies and RMSEs

388 obtained with $\sigma$ parameters using $\phi_{1}$ and $\phi_{2}$ uniformly over France, and with 
$\sigma$ parameters over the 7 major basins using $\phi_{2}$. Figure 8 shows the sorted efficiencies

390 and RMSEs obtained with $\sigma$ parameters using $\phi_{1}$ and $\phi_{2}$ uniformly over France. From

391 Table 1 and Figure 8 one can conclude that regardless of the optimization cost function

392 used, $\sigma$ parameters allow to obtain better results than $\rho$ parameters. Therefore, taking

393 topography into account in the travel time of the flow wave is advantageous. Similarly,

394 regardless of the parameters used and of the spatial resolution of the optimization,

395 optimizing using $\phi_{2}$ allows obtaining better average results than with $\phi_{1}$. The average

396 results obtained using $\sigma$ parameters and $\phi_{2}$ are comparable (slightly better) than those

397 obtained by the original routing module of SIM-France. One should note however, that

398 the best stations with MODCOU are better than the best with RAPID, while the worse

399 stations in MODCOU are worse than the worst in RAPID. This suggests a flattening of

400 the curves most likely due to equal treatment of all stations in the $\phi_{2}$ cost function.

401 Finally, regardless of the cost function used in optimization or the set of parameters

$402(\sigma$ and $\rho$ ) basin and sub-basin optimizations have a limited effect on overall

403 performance of RAPID. This suggests that increased inter-basin and intra-basin

404 variability of river routing parameters has little effect on efficiency or RMSE at the

405 spatial scale of France as it is modeled in SIM-France.

406 3.2. Comparison of routing schemes over 10 years

407 Over 1995-2005, only 3 gaging stations have a full daily record. Therefore, results

408 presented in this section are using stations with gaps in observations; efficiency and

409 RMSE are calculated only at times when measurements are available. A threshold of

$41070 \%$ of daily measurements available over $1995-2005$ leads to selecting 493 gaging 
411 stations. These stations differ slightly from the ones used in 1995-1996. Out of the 493

412 stations that have full daily record in 1995-1996, 436 stations are included in the 1995-

4132005 period. Similarly, out of the best 291 stations that have full daily record in 1995-

414 1996, 261 are included in 1995-2005. During 1995-2005, 427 out of the 493 stations

415 have a positive efficiency using the standard version of SIM-France. Table 1 shows

416 average statistics for $1995-2005$ for the best 427 values for both efficiency and RMSE,

417 but similar patterns are found for all 493 values. The conclusions drawn in Section 3.2.

418 regarding the sets of parameters, the cost functions and the spatial resolution of the

419 optimization are still valid for the ten-year simulation. However, one should note that

420 over ten years, MODCOU performs slightly better than RAPID using the best set of

421 options. This may be explained by the slightly different stations used for the 5-month

422 optimization and for the ten-year study. However, five months of the first year seem to

423 be sufficient to capture RAPID parameters and allow comparable performance between

424 MODCOU and RAPID over ten years. Figure 9 shows the sorted efficiencies and

425 RMSEs obtained with MODCOU and with RAPID with $\sigma$ parameters optimized

426 uniformly over France using $\phi_{2}$. Globally the two models perform comparably although,

427 similarly to $1995-1996$ results, the best stations are degraded and some stations with low

428 but positive efficiency are improved. Figure 10 shows observations and modeled

429 hydrographs during 1995-1996 and 1995-2005 for the Meuse River at Stenay (the

430 location of this station is shown in Figure 11) in which MODCOU and RAPID are almost

431 indiscernible. One should note, however, that in all the hydrographs plotted (not shown)

432 the timing of events differs slightly between the two models, none of which being 
433 consistently better than the other regardless of the optimization options as expected from

434 results shown in Table 1 and Figure 9.

435 Figure 11 shows a spatial comparison of efficiencies obtained over France.

436 Improvements and degradations of statistical results between MODCOU and RAPID

437 have no particular spatial patterns. Overall, the discharge simulated by MODCOU and

438 RAPID are similar in RMSE and Nash efficiency. This similarity can be explained by

439 the strong dependence of discharge calculations on the lateral inflow forcing which is the

440 same for both river routing schemes. Furthermore, the routing equations used in

441 MODCOU and RAPID are comparable (the linear reservoir equation in SIM-France is a

442 simplified Muskingum equation, given $\mathrm{x}=0$ ). The addition of RAPID to SIM-France can

443 be regarded as advantageous since RAPID provides with flow and volume of water in all

444 the cells of the river network separately and provides flexibility in the number and

445 location of river gages, which was not the case in the original version of SIM-France.

446 Also, the 30-min time step in RAPID allows potential comparisons with observations at

447 higher temporal resolution than the 3-hour time step of MODCOU. Finally, RAPID is

448 better suited than MODCOU for computation of river flow height in all grid cells of the

449 river network separately hence allowing the study of river-aquifer exchanges as shown in

450 Saleh et al. [2010; 2011].

\section{3.3. Influence of dams on river flow}

452 RAPID does not have a specific physical model for treatment of dams. However, the

453 model is designed such that observations at gaging stations can easily be substituted for

454 upstream flow. This capability is not available in the routing scheme of MODCOU and

455 is useful for a gaging station located at the outlet of a dam because the flows discharging 
456 from man-made infrastructures reflect human decisions. In France, the quality of flow 457 calculations at the outlet of the Rhône River (at Beaucaire) is influenced by the dam at 458 the outlet of Lake Geneva. Figure 12 demonstrates the influence of forcing with 459 observations at Pougny (downstream of the dam) on the calculation of flow at the outlet 460 of the Rhône River Basin. The gaging station a Pougny is the outlet of the "Rhône 461 upstream" basin in Figure 5b) and is also shown on Figure 11. The first year (August $1^{\text {st }}$ $4621995-$ July $31^{\text {st }} 1996$ ) was used for this experiment. Forcing with observations at Lake 463 Geneva increases the Nash Efficiency from 0.49 to 0.62 at Beaucaire, the outlet of the 464 Rhône basin. 


\section{Conclusions}

467 The river routing in SIM-France is done by MODCOU which uses groups of cells called

468 isochrone zones for its computations and does not directly compute flow and volume of

469 water for each cell of its quad-tree river network. The use of isochrones limits the

470 flexibility in the number and location of river gages. The work in this paper presents the

471 replacement of the river routing module in MODCOU by the river network model called

472 RAPID. Information on the network connectivity between the quad-tree river cells of

473 SIM-France is readily available in tables that relate upstream and downstream cells.

474 These tables can be used directly to create the network matrix of RAPID. A ten-year

475 study of river flow in Metropolitan France is presented comparing RAPID and the

476 routing module of MODCOU. An automated procedure for determining optimal model

477 parameters is available in RAPID and various options for the estimation of the

478 parameters are investigated. Sub-basin optimization increases model performance but its

479 influence is much smaller than the choice of the cost function. A cost function was

480 developed that normalizes the square-error between observations at each river gage and

481 RAPID computations by the average flow at the gage. This cost function is found to

482 globally increase the Nash efficiency of computed flow in all gages. We suggest that this

483 is due to the average flow having an influence on the computation of the Nash efficiency.

484 Therefore, the use of an appropriate criterion for quantifying the quality of river flow as

485 the cost function for the optimization procedure helps the betterment of model

486 computations. Also, flow wave celerities included in the temporal parameter of the

487 Muskingum method benefit from taking into account topography when compared to a

488 simple constant celerity formulation. Overall, the computation obtained with the addition 
489 of RAPID are comparable to those of the original river routing module in SIM-France.

490 We consider the addition of RAPID as advantageous since flow and volume of water is

491 directly computed for each cell of the quad-tree river network. The formulation of

492 RAPID allows for easily substituting observed flows for the upstream calculated flow,

493 which is advantageous when considering a man-made infrastructure as was shown for the

494 Rhône River.

495 


\section{Acknowledgments}

497 This work was partially supported by the French MinesParistech, by the French Agence 498 Nationale de la Recherche under the Vulnérabilité de la nappe du Rhin (VulNaR) project, 499 by the French Programme Interdisciplinaire de Recherche sur l'Environnement de la 500 Seine (PIREN-Seine) project, by the U.S. National Aeronautics and Space Administration 501 under the Interdisciplinary Science Project NNX07AL79G, by the U.S. National Science

502 Foundation under project EAR-0413265: CUAHSI Hydrologic Information Systems, and 503 by the American Geophysical Union under a Horton (Hydrology) Research Grant.

504 Thank you to Pere Quintana-Seguí for discussion about and for sharing data 505 corresponding to his work on SIM-France. Thank you to Firas Saleh and to Céline

506 Monteil for discussions on travel time within SIM-France. The authors are thankful to 507 the two anonymous reviewers and to the editor for their valuable comments and 508 suggestions that helped improved the original version of this manuscript. 


\section{References}

511 Abdulla, F. A., D. P. Lettenmaier, E. F. Wood, and J. A. Smith (1996), Application of a

512 macroscale hydrologic model to estimate the water balance of the Arkansas Red River

513 basin, Journal of Geophysical Research-Atmospheres, 101, 7449-7459.

514 Boone, A., J.-C. Calvet, J. Noilhan, and euml (1999), Inclusion of a Third Soil Layer in a

515 Land Surface Scheme Using the Force-Restore Method, Journal of Applied Meteorology,

$51638,1611-1630$.

517 Cunge, J. A. (1969), On the subject of a flood propagation computation method

518 (Muskingum method), Journal of Hydraulic Research, 7, 205-230.

519 David, C. H., D. R. Maidment, G.-Y. Niu, Z.-L. Yang, F. Habets, and V. Eijkhout (2011),

520 River network routing on the NHDPlus dataset, Journal of Hydrometeorology, tentatively

521 accepted on 18 January 2011.

522 Decharme, B., H. Douville, A. Boone, F. Habets, and J. Noilhan (2006), Impact of an

523 Exponential Profile of Saturated Hydraulic Conductivity within the ISBA LSM:

524 Simulations over the RhÃ'ne Basin, Journal of Hydrometeorology, 7, 61-80.

525 Ducharne, A., C. Golaz, E. Leblois, K. Laval, J. Polcher, E. Ledoux, and G. de Marsily

526 (2003), Development of a high resolution runoff routing model, calibration and

527 application to assess runoff from the LMD GCM, Journal of Hydrology, 280, 207-228.

528 Durand, Y., E. Brun, L. Mérindol, G. Guyomarc'h, B. Lesaffre, and E. Martin (1993), A

529 meteorogical estimation of relevant parameters for snow models, Annals of Glaciology, $53018,65-71$.

531 Habets, F., A. Boone, J. L. Champeaux, P. Etchevers, L. Franchisteguy, E. Leblois, E.

532 Ledoux, P. Le Moigne, E. Martin, S. Morel, J. Noilhan, P. Q. Segui, F. Rousset- 
533 Regimbeau, and P. Viennot (2008), The SAFRAN-ISBA-MODCOU

534 hydrometeorological model applied over France, Journal of Geophysical Research-

535 Atmospheres, 113.

536 Leblanc, D., and J. P. Villeneuve (1978), Algorithme de schématisation des écoulements

537 d'un bassin versant 1-55 pp, Institut national de la recherche scientifique, Québec.

538 Leblois, E., and E. Sauquet (2000), Grid elevation models in hydrology. Part 2:

539 HydroDem technical note, $80 \mathrm{pp}$, Cemagref, Lyon.

540 Ledoux, E., G. Girard, G. de Marsily, J. P. Villeneuve, and J. Deschenes (1989), Spatially

541 Distributed Modeling: Conceptual Approach, Coupling Surface Water and Groundwater,

542 in Unsaturated Flow in Hydrologic Modeling Theory and Practice, edited by H. J.

543 Morel-Seytoux, pp. 435-454, Kluwer Academic Publishers.

544 Lohmann, D., R. NolteHolube, and E. Raschke (1996), A large-scale horizontal routing

545 model to be coupled to land surface parametrization schemes, Tellus Series a-Dynamic

546 Meteorology and Oceanography, 48, 708-721.

547 Lohmann, D., D. P. Lettenmaier, X. Liang, E. F. Wood, A. Boone, S. Chang, F. Chen, Y.

548 J. Dai, C. Desborough, R. E. Dickinson, Q. Y. Duan, M. Ek, Y. M. Gusev, F. Habets, P.

549 Irannejad, R. Koster, K. E. Mitchell, O. N. Nasonova, J. Noilhan, J. Schaake, A.

550 Schlosser, Y. P. Shao, A. B. Shmakin, D. Verseghy, K. Warrach, P. Wetzel, Y. K. Xue,

551 Z. L. Yang, and Q. C. Zeng (1998a), The Project for Intercomparison of Land-surface

552 Parameterization Schemes (PILPS) phase 2(c) Red-Arkansas River basin experiment: 3.

553 Spatial and temporal analysis of water fluxes, Global and Planetary Change, 19, 161-

554179. 
555 Lohmann, D., E. Raschke, B. Nijssen, and D. P. Lettenmaier (1998b), Regional scale

556 hydrology: I. Formulation of the VIC-2L model coupled to a routing model, Hydrological

557 Sciences Journal-Journal Des Sciences Hydrologiques, 43, 131-141.

558 Lohmann, D., E. Raschke, B. Nijssen, and D. P. Lettenmaier (1998c), Regional scale

559 hydrology: II. Application of the VIC-2L model to the Weser River, Germany,

560 Hydrological Sciences Journal-Journal Des Sciences Hydrologiques, 43, 143-158.

561 Lohmann, D., K. E. Mitchell, P. R. Houser, E. F. Wood, J. C. Schaake, A. Robock, B. A.

562 Cosgrove, J. Sheffield, Q. Y. Duan, L. F. Luo, R. W. Higgins, R. T. Pinker, and J. D.

563 Tarpley (2004), Streamflow and water balance intercomparisons of four land surface

564 models in the North American Land Data Assimilation System project, Journal of

565 Geophysical Research-Atmospheres, 109, 1-22.

566 Maurer, E. P., G. M. O'Donnell, D. P. Lettenmaier, and J. O. Roads (2001), Evaluation of

567 the land surface water budget in NCEP/NCAR and NCEP/DOE reanalyses using an off-

568 line hydrologic model, Journal of Geophysical Research-Atmospheres, 106, 17841-

56917862.

570 Nash, J. E., and J. V. Sutcliffe (1970), River flow forecasting through conceptual models

571 part I -- A discussion of principles, Journal of Hydrology, 10, 282-290.

572 Nelder, J. A., and R. Mead (1965), A Simplex Method for Function Minimization, The

573 Computer Journal, 7, 308-313.

574 Ngo-Duc, T., T. Oki, and S. Kanae (2007), A variable streamflow velocity method for

575 global river routing model: model description and preliminary results, Hydrol. Earth Syst.

576 Sci. Discuss., 4, 4389-4414. 
577 Nijssen, B., D. P. Lettenmaier, X. Liang, S. W. Wetzel, and E. F. Wood (1997),

578 Streamflow simulation for continental-scale river basins, Water Resources Research, 33, $579 \quad 711-724$

580 Noilhan, J., and S. Planton (1989), A Simple Parameterization of Land Surface Processes

581 for Meteorological Models, Monthly Weather Review, 117, 536-549.

582 Oki, T., and Y. C. Sud (1998), Design of Total Runoff Integrating Pathways (TRIP) - A

583 Global River Channel Network, Earth Interactions, 2, 1-35.

584 Olivera, F., J. Famiglietti, and K. Asante (2000), Global-scale flow routing using a

585 source-to-sink algorithm, Water Resources Research, 36, 2197-2207.

586 Quintana-Seguỉ, P., P. Le Moigne, Y. Durand, E. Martin, F. Habets, M. Baillon, C.

587 Canellas, L. Franchisteguy, and S. Morel (2008), Analysis of near-surface atmospheric

588 variables: Validation of the SAFRAN analysis over France, Journal of Applied

589 Meteorology and Climatology, 47, 92-107.

590 Quintana-Seguỉ, P., E. Martin, F. Habets, and J. Noilhan (2009), Improvement, 591 calibration and validation of a distributed hydrological model over France, Hydrol. Earth 592 Syst. Sci., 13, 163-181.

593 Saleh, F. S. M., N. Flipo, F. Habets, A. Ducharne, L. Oudin, M. Poulin, P. Viennot, and

594 E. Ledoux (2010), CONTRIBUTION OF 1D RIVER FLOW MODELING TO THE

595 QUANTIFICATION OF STREAM-AQUIFER INTERACTIONS IN A REGIONAL

596 HYDROLOGICAL MODEL, paper presented at XVIII International Conference on

597 Computational Methods in Water Resources (CMWR 2010)

598 CMWR 2010, Barcelona. 
599 Saleh, F. S. M., N. Flipo, F. Habets, A. Ducharne, L. Oudin, P. Viennot, and E. Ledoux

600 (2011), Modeling the impact of in-stream water level fluctuations on stream-aquifer

601 interactions at the regional scale, Journal of Hydrology, accepted.

602 SCHAPI (2008), Banque HYDRO, Service Central d'Hydrométéorologie et d'Appui à la

603 Prévision des Inondations available online at http://www.hydro.eaufrance.fr/index.php.

604 USEPA, and USGS (2007), NHDPlus User Guide, available online at

605 http://www.horizon-systems.com/nhdplus/documentation.php.

606 Wetzel, S. (1994), A hydrological model for predicting the effects of climate change, 85

607 pp, Princeton University, Princeton.

608

609 
610 Table 1 Average efficiencies and average root mean square errors computed for MODCOU and for RAPID with 7 different

611 sets of parameters. The best 382 values are used for 1995-1996 and the best 427 values are used for 1995-2005.

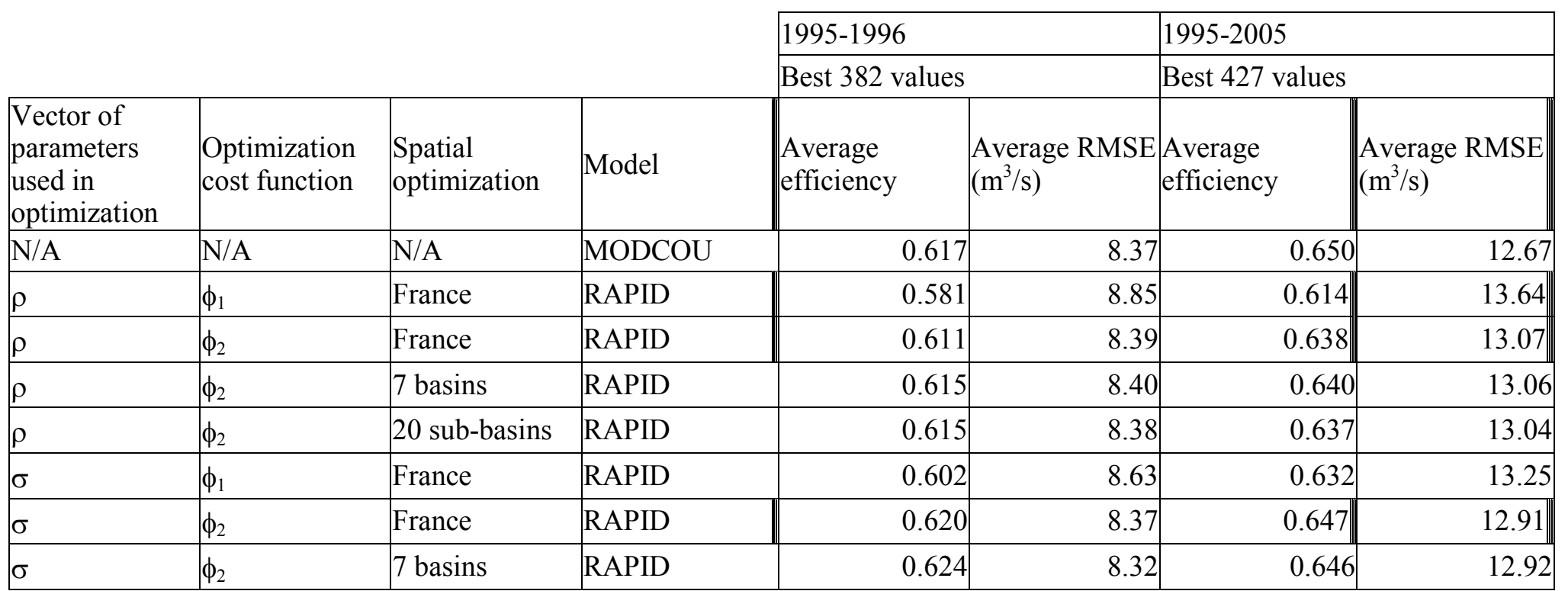

612 
613 Table 2 Results of optimization procedure using $\rho$ parameters and the $\phi_{2}$ cost function

\begin{tabular}{|c|c|c|c|c|c|c|c|c|c|c|c|c|c|}
\hline Basin & Sub-basin & $\begin{array}{l}\text { Number of } \\
\text { river cells }\end{array}$ & $\begin{array}{l}\text { Number of } \\
\text { stations }\end{array}$ & $\begin{array}{c}\text { Observa- } \\
\text { bility ratio }\end{array}$ & $\begin{array}{c}\text { Optimized } \\
\lambda_{\mathrm{k}}\end{array}$ & $\begin{array}{c}\text { Optimized } \\
\lambda_{\mathrm{x}}\end{array}$ & Basin & $\begin{array}{l}\text { Sub- } \\
\text { basin }\end{array}$ & $\begin{array}{c}\text { Number of river } \\
\text { cells }\end{array}$ & $\begin{array}{l}\text { Number of } \\
\text { stations }\end{array}$ & $\begin{array}{c}\text { Observa- } \\
\text { bility } \\
\text { ratio }\end{array}$ & $\begin{array}{c}\text { Optimized } \\
\lambda_{\mathrm{k}}\end{array}$ & $\begin{array}{c}\text { Optimized } \\
\lambda_{\mathrm{x}}\end{array}$ \\
\hline France & all basin & 24264 & 291 & 83.4 & 0.366 & 0.237 & Loire & \begin{tabular}{|c|} 
Loire \\
downstre \\
am
\end{tabular} & 1763 & 25 & 70.5 & 0.436 & 0.091 \\
\hline Adour & all basin & 666 & 9 & 74.0 & 0.375 & 0.313 & Seine & all basin & 5115 & 41 & 124.8 & 0.531 & 0.234 \\
\hline Garonne & all basin & 2985 & 58 & 51.5 & 0.294 & 0.009 & Seine & $\begin{array}{c}\begin{array}{c}\text { Seine } \\
\text { upstream }\end{array} \\
\end{array}$ & 2919 & 30 & 97.3 & 0.579 & 0.145 \\
\hline Garonne & $\begin{array}{l}\text { Garonne } \\
\text { upstream }\end{array}$ & 558 & 5 & 111.6 & 0.160 & 0.420 & Seine & Oise & 889 & 10 & 88.9 & 0.469 & 3.766 \\
\hline Garonne & Tarn & 356 & 8 & 44.5 & 0.152 & 0.674 & Seine & \begin{tabular}{|c|} 
Seine \\
downstre \\
am \\
\end{tabular} & 1307 & 1 & 1307.0 & 0.031 & 4.984 \\
\hline Garonne & Lot & 369 & 10 & 36.9 & 0.394 & 0.113 & Meuse & all basin & 832 & 3 & 277.3 & 0.383 & 0.059 \\
\hline Garonne & Dordogne & 431 & 12 & 35.9 & 0.356 & 0.056 & Rhône & all basin & 3426 & 51 & 67.2 & 0.256 & 0.118 \\
\hline Garonne & $\begin{array}{c}\text { Garonne } \\
\text { downstream }\end{array}$ & 1271 & 23 & 55.3 & 0.375 & 0.313 & Rhône & Saône & 1043 & 32 & 32.6 & 0.236 & 0.007 \\
\hline Loire & all basin & 4138 & 88 & 47.0 & 0.414 & 0.197 & Rhône & Ardèche & 66 & 3 & 22.0 & 0.000 & 0.156 \\
\hline Loire & Vienne & 706 & 20 & 35.3 & 0.386 & 0.145 & Rhône & \begin{tabular}{|c|} 
Rhône \\
upstream
\end{tabular} & 279 & 1 & 279.0 & 0.500 & 4.750 \\
\hline Loire & Allier & 458 & 17 & 26.9 & 0.308 & 2.670 & Rhône & $\begin{array}{c}\text { Rhône } \\
\text { downstre } \\
\text { am }\end{array}$ & 2038 & 15 & 135.9 & 0.403 & 0.076 \\
\hline Loire & $\begin{array}{c}\text { Loire } \\
\text { upstream }\end{array}$ & 541 & 12 & 45.1 & 0.391 & 0.305 & Hérault & Hérault & 101 & 3 & 33.7 & 0.375 & 4.813 \\
\hline Loire & Loir & 670 & 14 & 47.9 & 0.453 & 0.273 & & & & & & & \\
\hline
\end{tabular}

614 


\section{Captions to illustrations}

616

617 
618

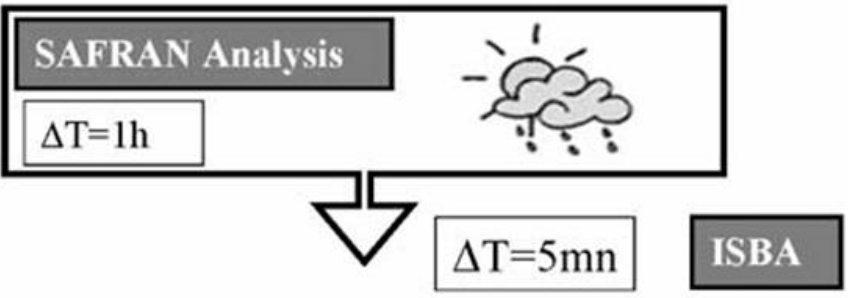

620 Figure 1 Structure of SIM-France, from Habets et al. [2008]

621 


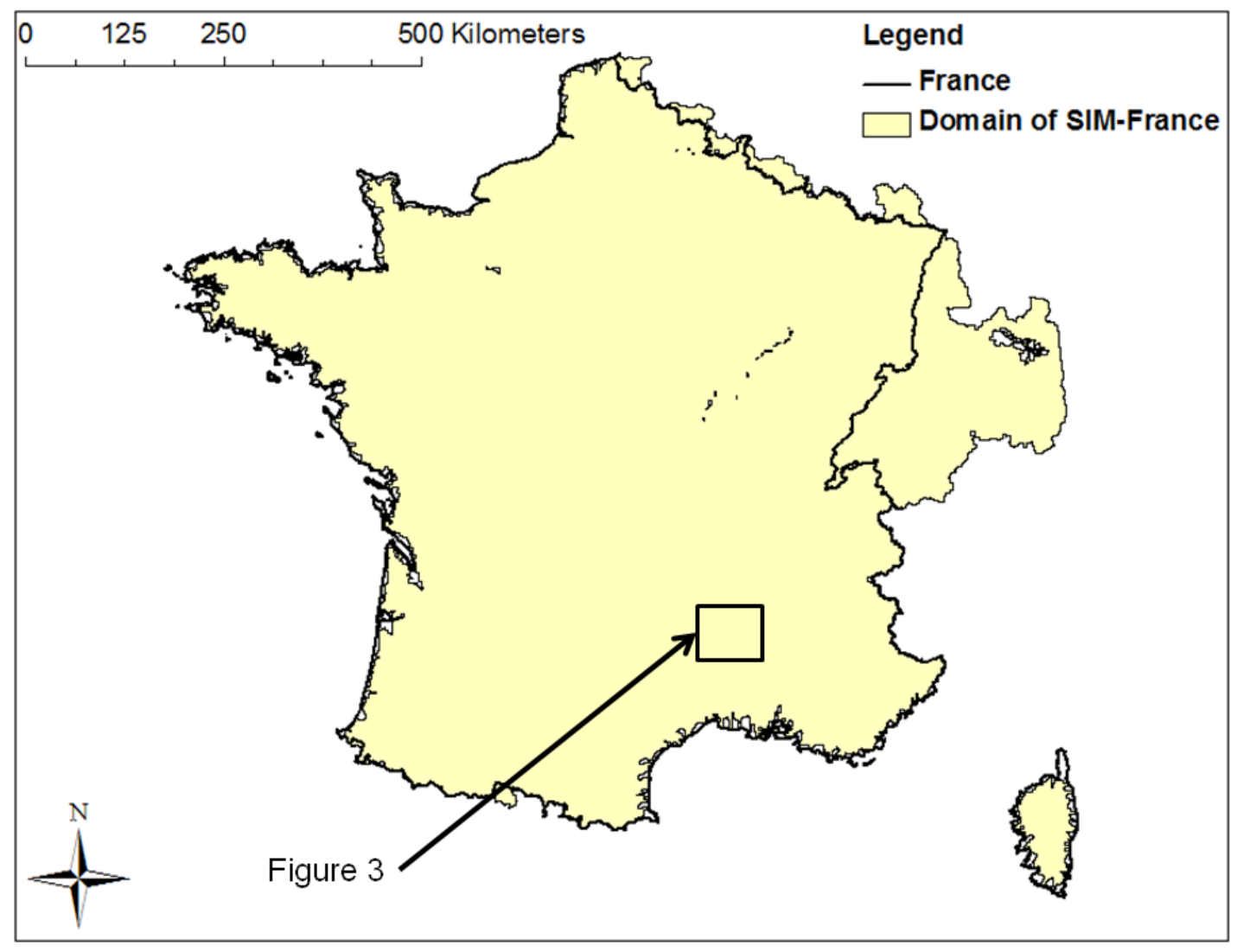

622

623 Figure 2 France and computational domain of SIM-France

624 

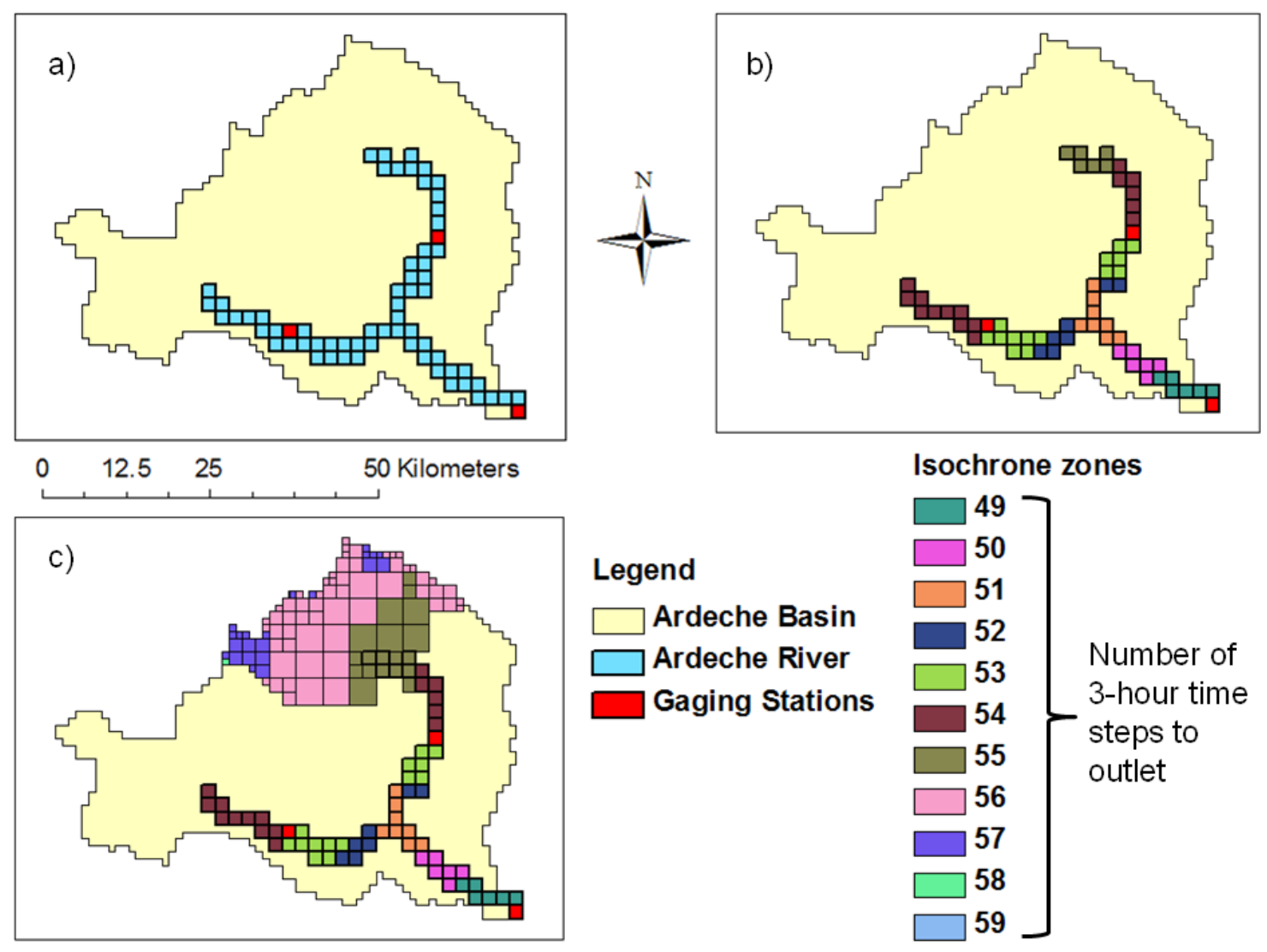

626 Figure 3 Surface and river isochrone zones in Ardèche Basin in MODCOU within

\section{SIM-France}

628 


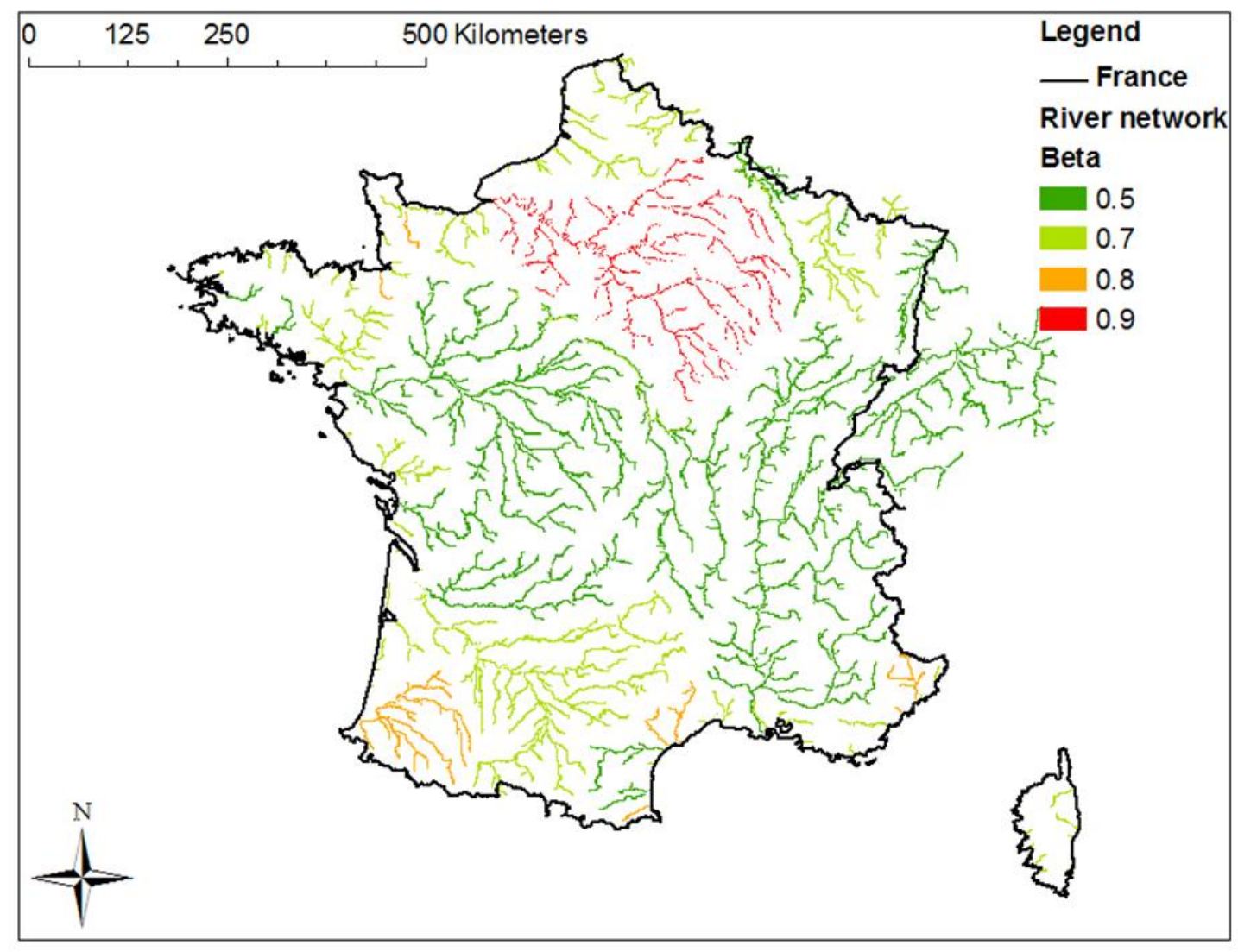

630 Figure 4 Map of the parameter $\beta$ used for river routing in MODCOU within SIM-

631 France

632 

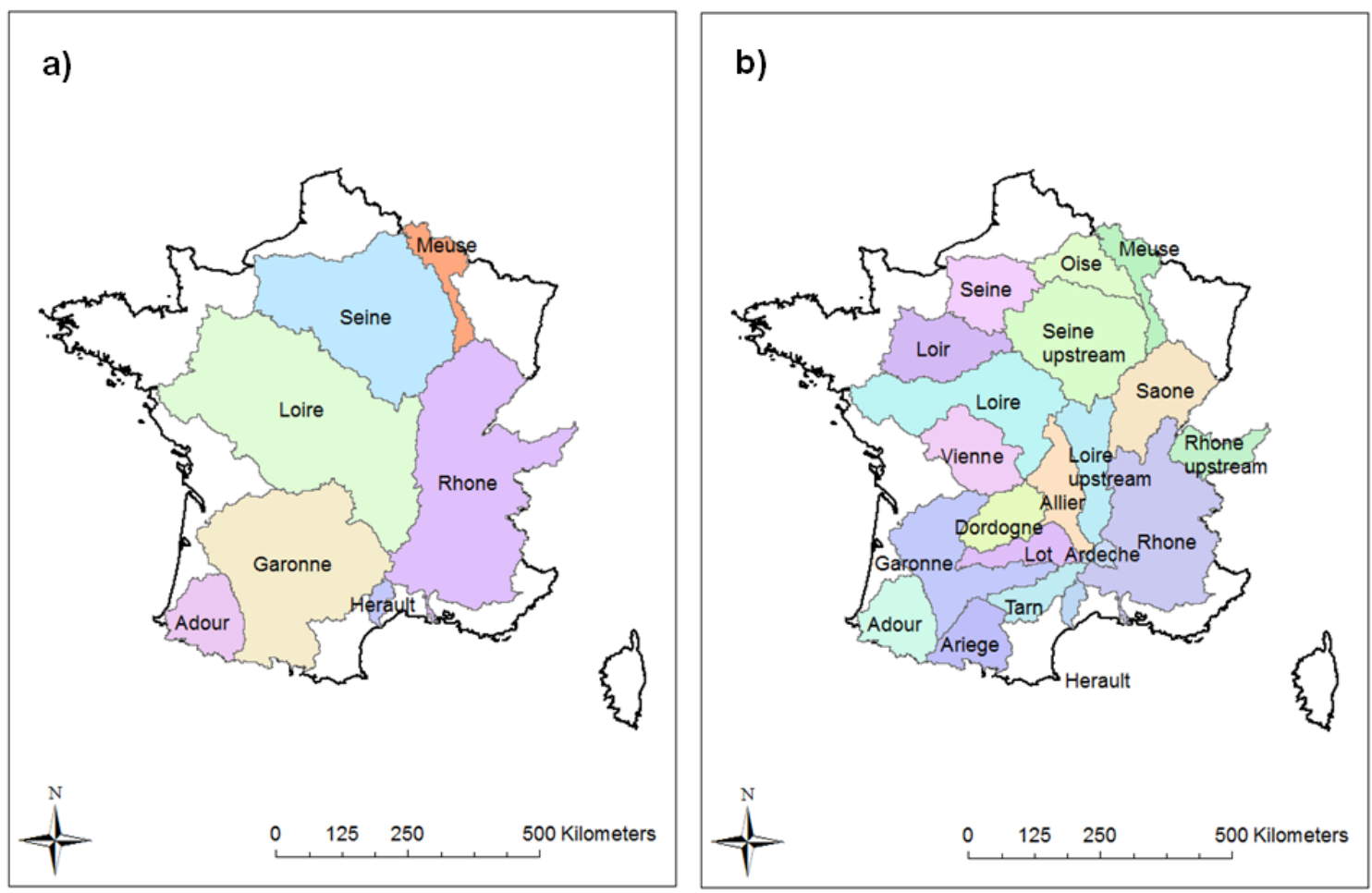

633

634 Figure 5 Basins treated independently during optimization of RAPID parameters in 635 SIM-France. a) Seven major river basins. b) Twenty sub-basins 636 
Sorted root mean square error

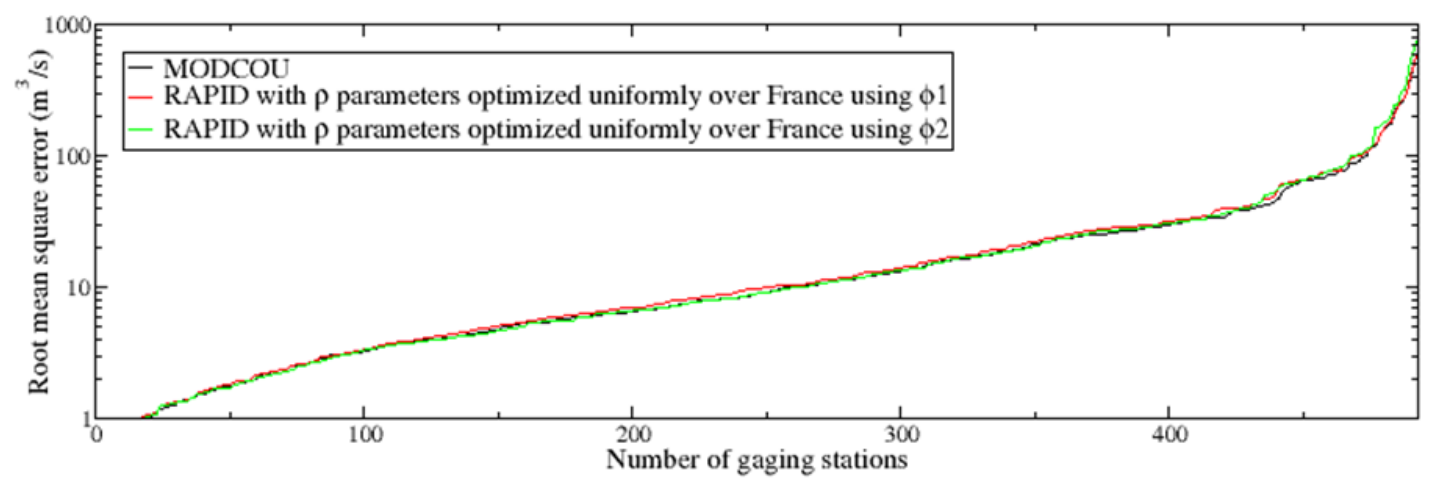

Sorted efficiency

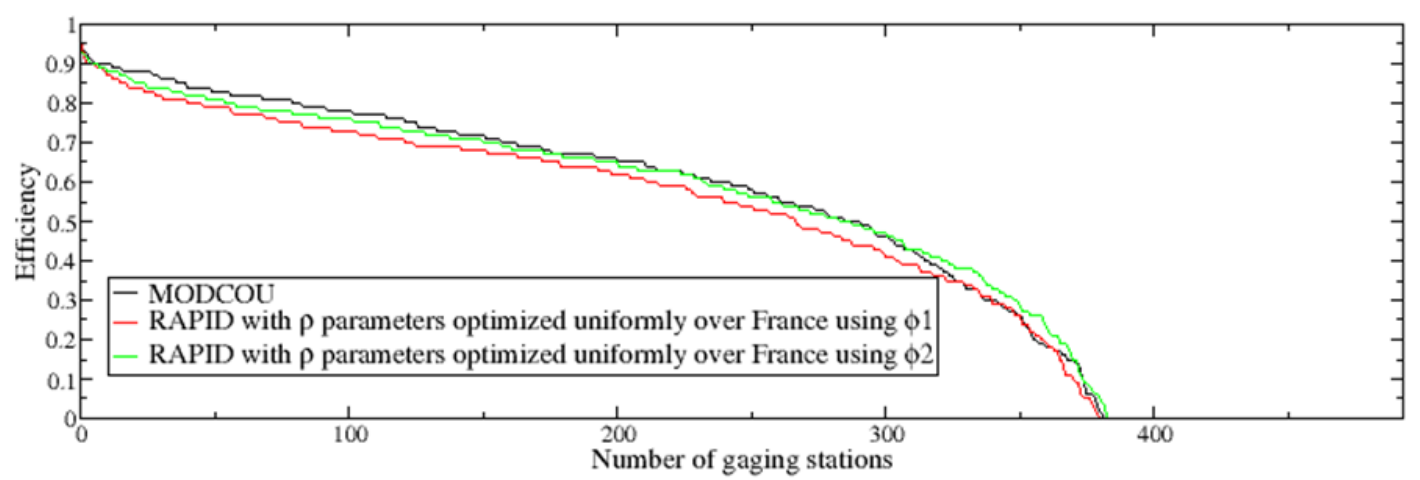

638 Figure 6 Comparison of sorted RMSEs and efficiencies for the year 1995-1996

639 between MODCOU and RAPID with $\rho$ parameters optimized uniformly over France

640 using the original cost function $\phi_{1}$ and using the new cost function $\phi_{2}$ 
Sorted root mean square error

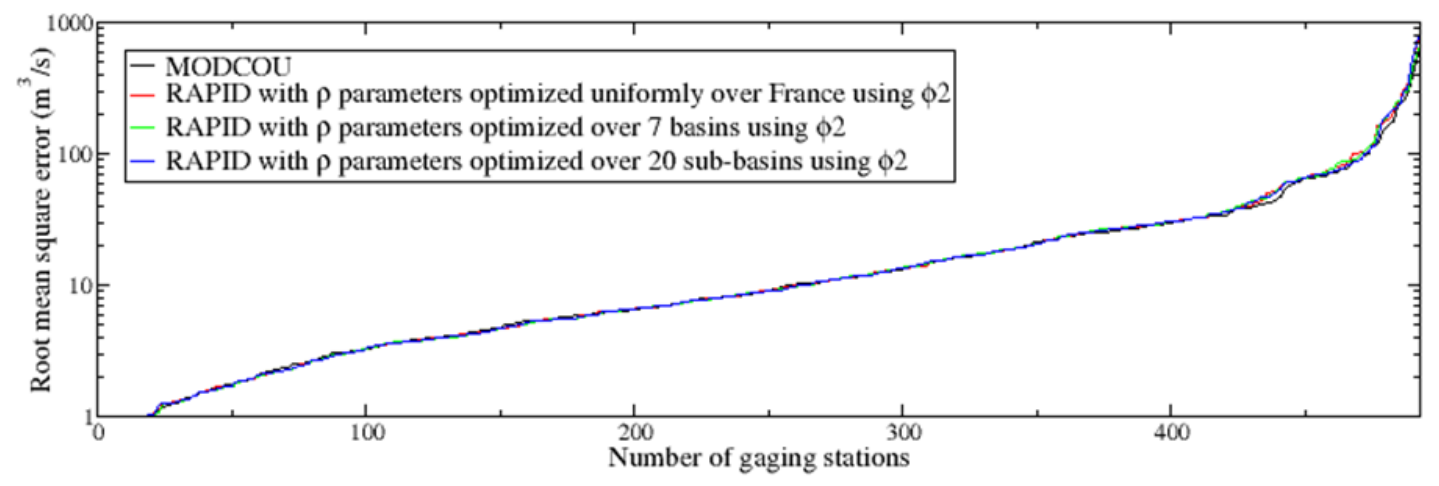

Sorted efficiency

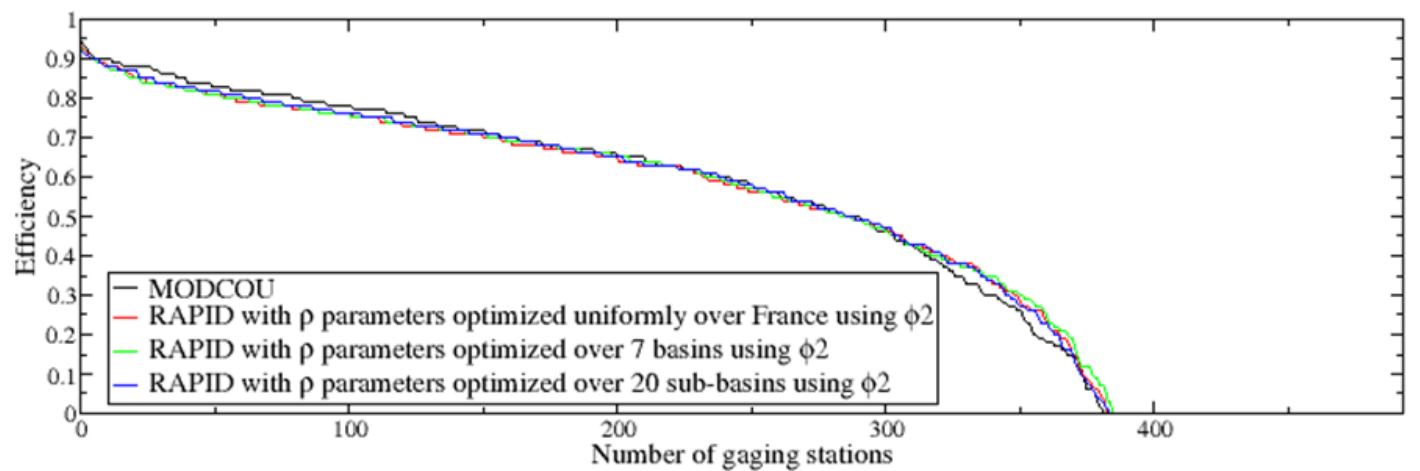

644 Figure $7 \quad$ Effect of sub-basin optimization for RAPID on RMSEs and efficiencies

645 for the year 1995-1996 with $\rho$ parameters using the new cost function $\phi_{2}$ 
Sorted root mean square error

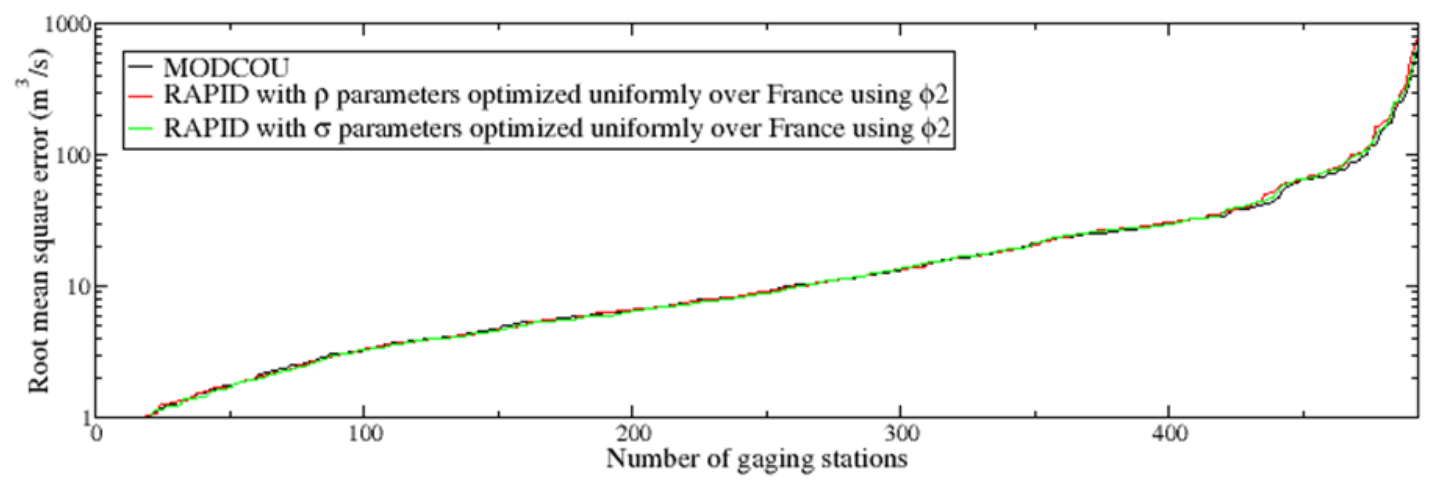

Sorted efficiency

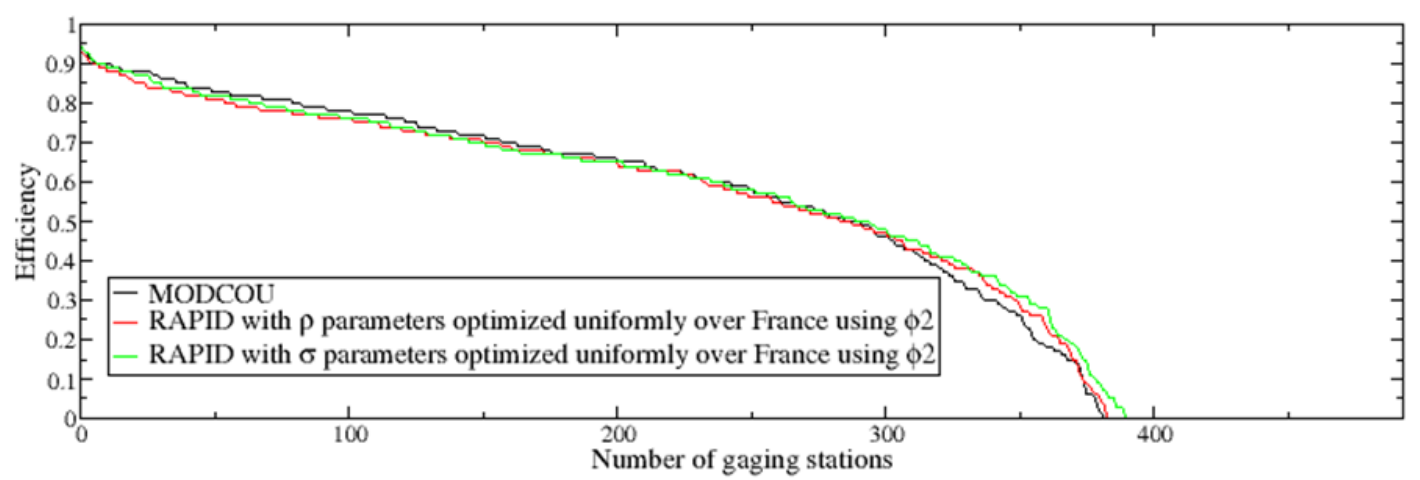

648 Figure $8 \quad$ Effect of set of parameters $\rho$ and $\sigma$ for RAPID on RMSEs and efficiencies

649 for the year 1995-1996 using the new cost function $\phi_{2}$ uniformly over France 

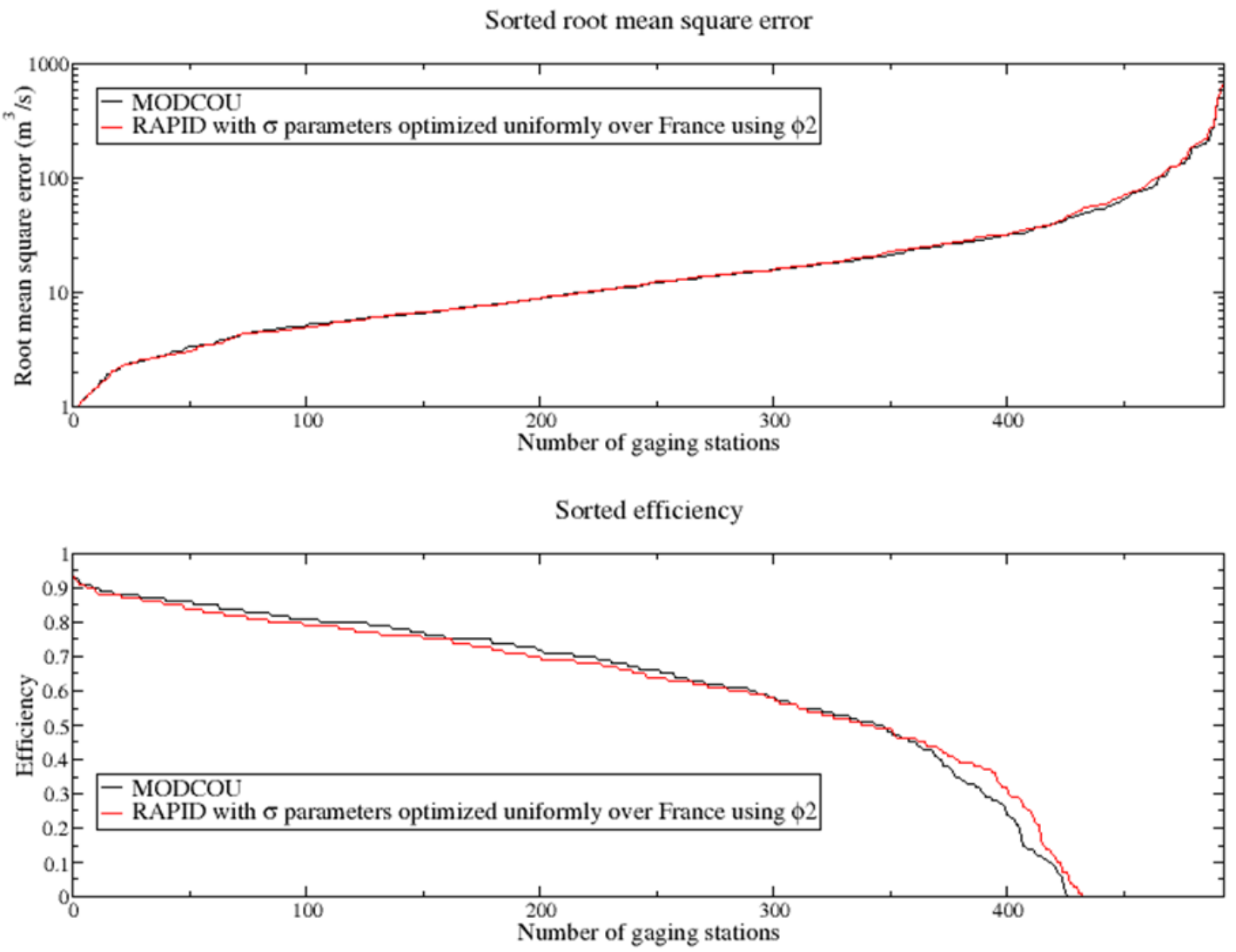

650

651 Figure 9 Comparison of sorted RMSEs and efficiencies for the years 1995-2005

652 between MODCOU and RAPID with $\sigma$ parameters optimized uniformly over France

653 using the new cost function $\phi_{2}$ 
Meuse River at Stenay

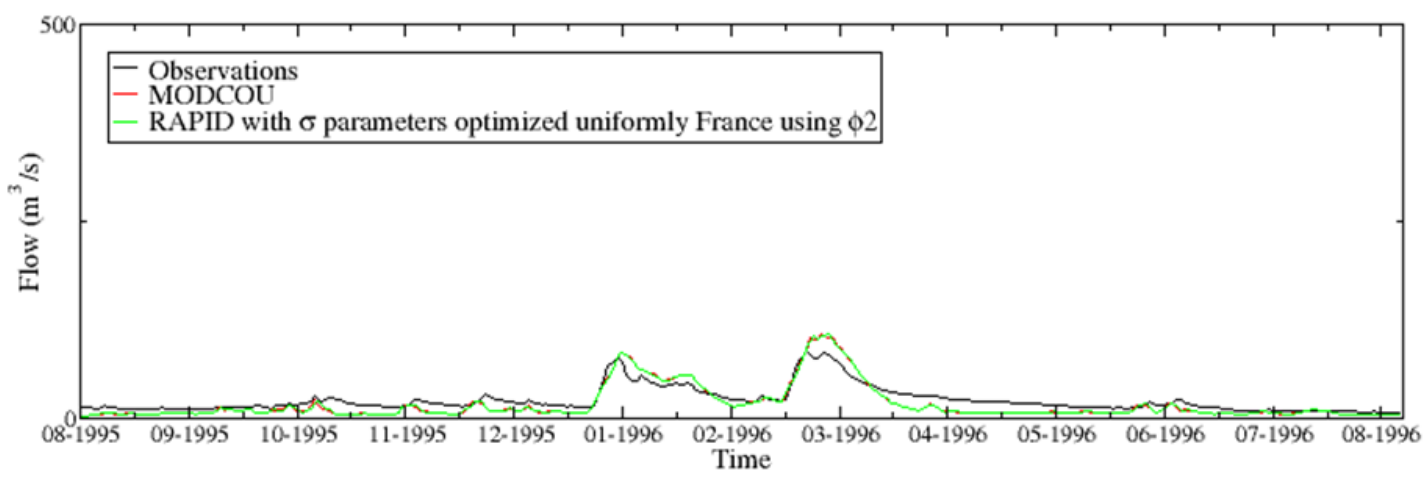

Meuse River at Stenay

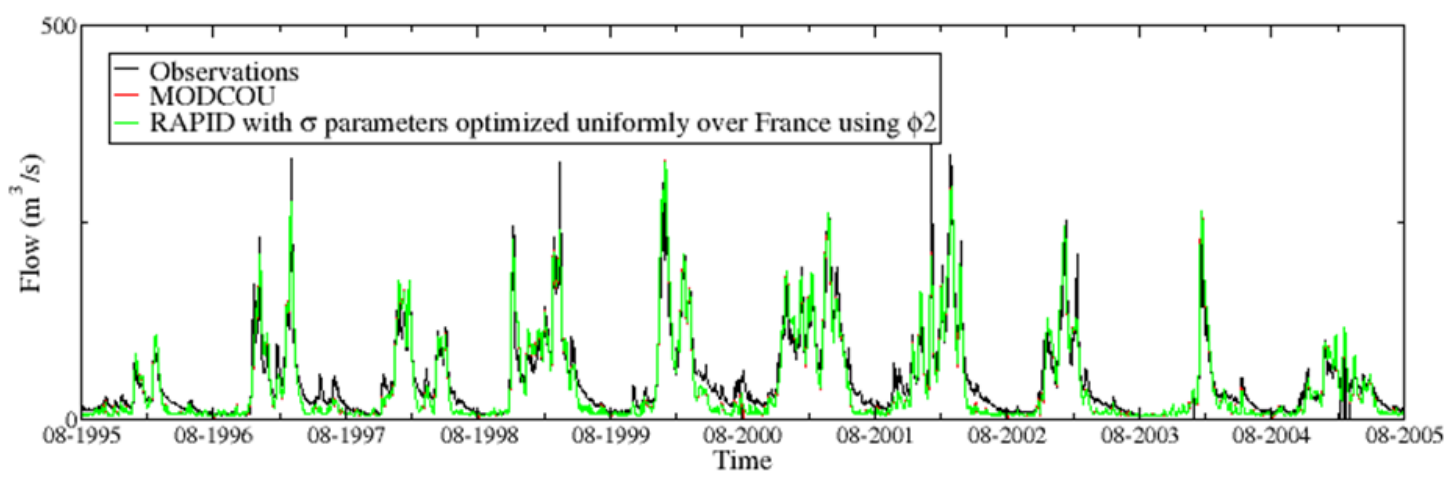

655 Figure 10 Comparison of 1995-1996 and 1995-2005 hydrographs for the Meuse

656 River at Stenay obtained by MODCOU and RAPID with $\sigma$ parameters optimized

657 uniformly over France using the new cost function $\phi_{2}$ 


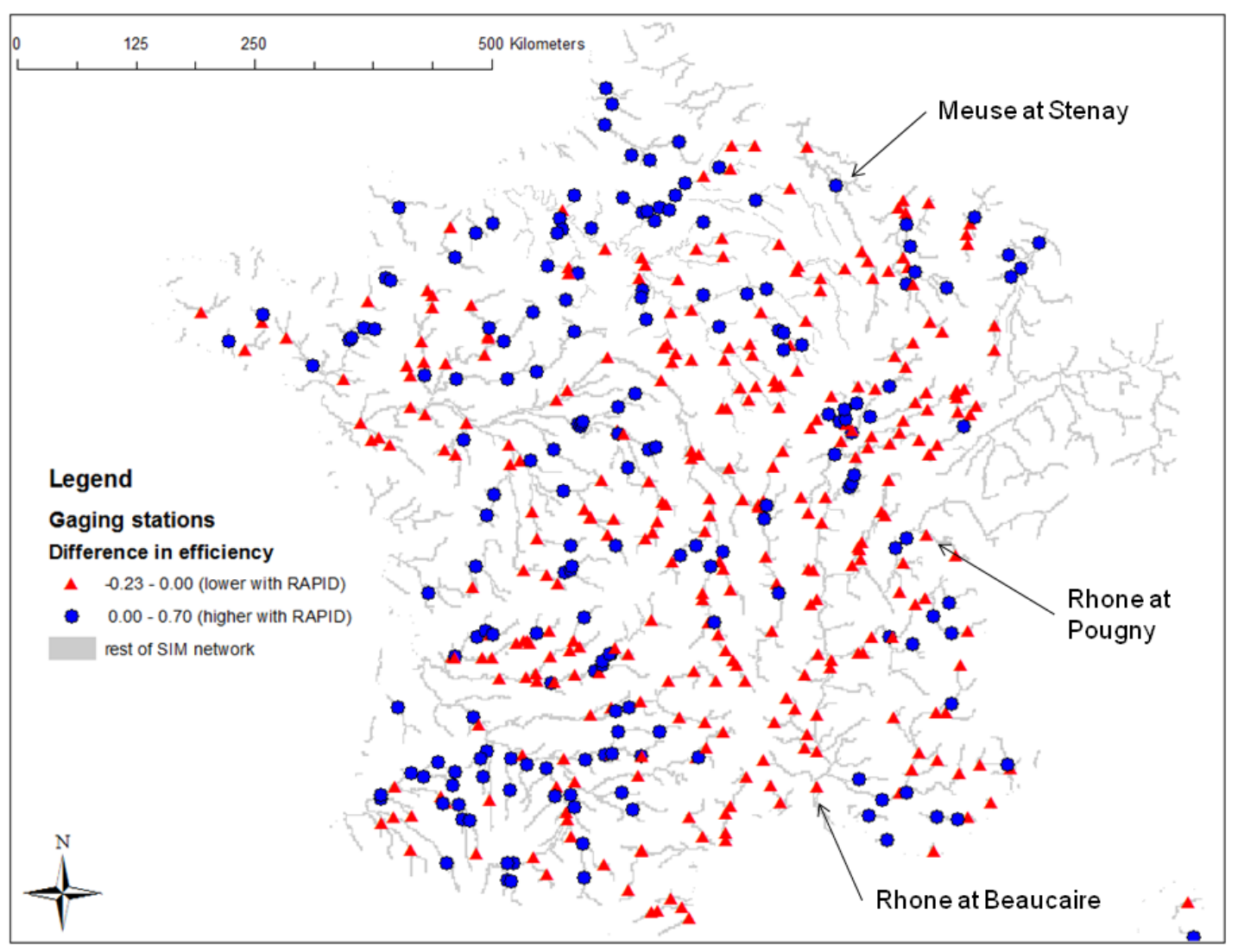

659 Figure $11 \quad$ Spatial difference of efficiencies obtained for the years 1995-2005

660 between RAPID using $\sigma$ parameters optimized uniformly over France using the new cost

661 function $\phi_{2}$ and MODCOU

662 
Influence of dam at Pougny on river flow at Beaucaire

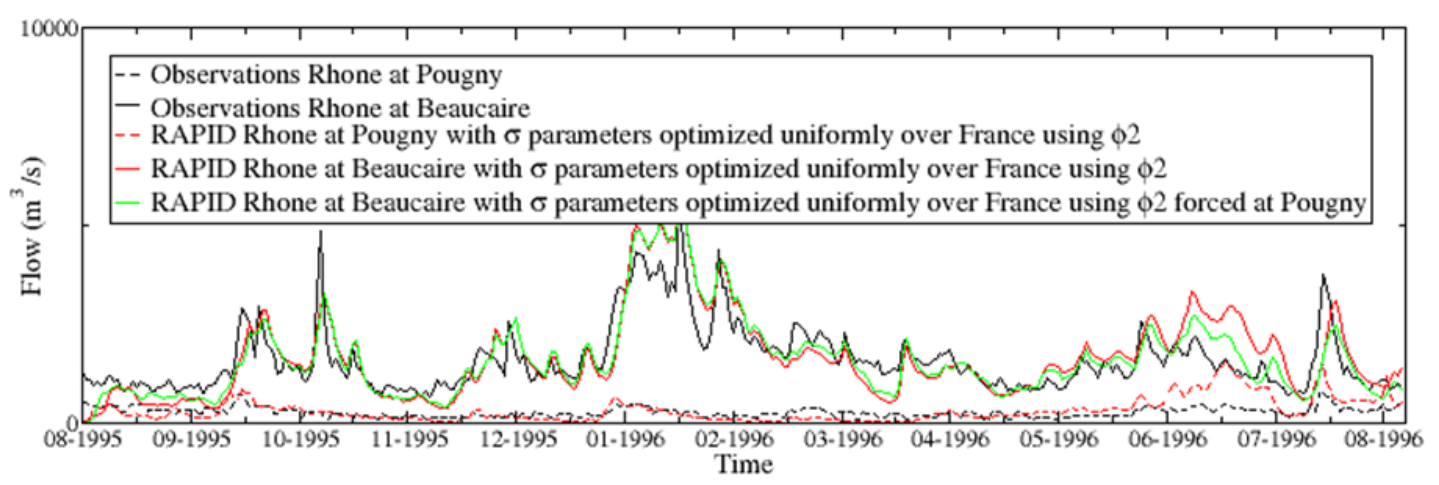

663

664 Figure 12 Comparison of RAPID discharge calculation at the outlet of the Rhône

665 River (at Beaucaire) with and without forcing at the outlet of Lake Geneva (at Pougny). 